\title{
ANALISIS KUALITAS PELAYANAN DAN KEPERCAYAAN TERHADAP KEPUASAN NASABAH BUMDES DESA WONOASRI KABUPATEN JEMBER
}

\author{
Auliannisa Vistya Dianty ${ }^{1}$, Trias Setyowati ${ }^{2}$, Tatit Diansari Reskiputri ${ }^{3}$ \\ 1,2,3Program Studi Manajemen, Universitas Muhammadiyah Jember \\ Jalan Gumuk Karang, Karangrejo, Sumbersari, Jember, 68124 \\ avistyad@gmail.com ${ }^{1}$, trias@unmuhjember.ac.id ${ }^{2}$
}

\begin{abstract}
Background - Efforts to improve service quality are very influential on the future of a company to foster trust and provide satisfaction to customers or consumers.

Objective - This study aims to determine how influential the service quality variables consisting of tangibles, responsiveness, reliability, assurance and empathy and the trust variables consisting of ability, benevolence, integrity on customer satisfaction BUMDes Dana Asri Sejahtera.

Design/Methodology/Approach - This research is causal associative research using quantitative technique. The data used in this study are primary data and secondary data, with a sample of 85 people.

Findings - Based on the results of the calculation of multiple linear regression analysis on the service quality variable, the most influential dimension is tangibles with a total of 1,264, while the most influential dimension of trust is ability with a total of 1.132. So the conclusion obtained is that the variables of service quality and trust have a significant effect simultaneously and partially on customer satisfaction.

Research implications - The results of this study have the implication that customer satisfaction can be increased through improving service quality and customer trust and can be a reference for the influence of service quality and trust on satisfaction, especially for BUMDes Dana Asri Sejahtera customers.

Research limitations - The limitations of this study are the number of respondents, which is only 85 people, of course, is still lacking to describe the real situation and the information provided by respondents through questionnaires sometimes does not show the actual events, because sometimes it is caused by differences in thoughts, assumptions and understandings of each respondent.
\end{abstract}

Keywords: : customer satisfaction, service quality, trust

\begin{abstract}
Abstrak
Latar Belakang - Upaya peningkatan kualitas pelayanan sangat berpengaruh terhadap masa depan sebuah perusahaan untuk menumbuhkan rasa percaya dan memberikan rasa puas terhadap pelanggan atau konsumennya.

Tujuan - Penelitian ini bertujuan untuk mengetahui seberapa berpengaruh variabel kualitas pelayanan yang terdiri dari tangibles, responsiveness, reliability, assurance dan empathy serta variabel kepercayaan yang terdiri dari ability, benevolence, integrity terhadap kepuasan nasabah BUMDes Dana Asri Sejahtera.

Desain / metodologi / pendekatan - Penelitian ini adalah penelitian asosiatif kausal menggunakan teknik kuantitatif. Data yang digunakan dalam penelitian ini adalah data primer dan data sekunder, dengan sampel berjumlah 85 orang.

Temuan - Berdasarkan hasil perhitungan analisis regresi linier berganda pada variebel kualitas pelayanan dimensi yang paling berpengaruh adalah tangibles dengan jumlah sebesar 1.264,
\end{abstract}

http://dx.doi.org/10.30587/mahasiswamanajemen.v2i01.2565

Program Studi Manajemen Universitas Muhammadiyah Gresik Jawa Timur Indonesia 
sedangkan pada variabel kepercayaan dimensi yang paling berpengaruh adalah ability dengan jumlah sebesar 1,132. Maka kesimpulan yang didapatkan adalah variabel kualitas pelayanan dan kepercayaan memiliki pengaruh signifikan secara simultan dan parsial terhadap kepuasan nasabah.

Implikasi penelitian - Hasil penelitian ini memiliki implikasi bahwa kepuasan pelanggan dapat ditingkatkan melalui peningkatan kualitas pelayanan dan kepercayaan nasabah serta dapat menjadi rujukan pengaruh kualitas pelayanan dan kepercayaan terhadap kepuasan khususnya nasabah BUMDes Dana Asri Sejahtera

Batasan penelitian - Keterbatasan penelitian ini adalah jumlah responden yang hanya 85 orang tentunya masih kurang untuk menggambarkan keadaan yang sesungguhnya dan informasi yang diberikan responden melalui kuesioner terkadang tidak menunjukkan kejadian yang sebenarnya, karena terkadang disebabkan oleh terjadinya perbedaan pemikiran, anggapan dan pemahaman pada setiap responden.

Kata kunci : kepuasan nasabah, kualitas pelayanan, kepercayaan

\section{PENDAHULUAN}

Pada era globalisasi dalam satu decade terakhir, peningkan kualitas atas jasa yang ditawarkan semakin mendapat banyak perhatian bagi masyarakat. Salah satunya dibidang jasa keuangan yang sedang mengalami oertumbuhan pesat, Pemberian pelayanan yang baik akan mampu memberi rasa puas kepada nasabah. Banyaknya perusahaan jasa yang terlibat dalam pemenuhan kebutuhan konsumen, mengharuskan perusahaan tersebut meningkatkan daya saing bisnis dan profesionalisme dalam pengelolaan bisnis agar mampu bersaing lebih unggul dalam memberikan pelayanan terhadap konsumennya juga agar dapat menjaga kepercayaan konsumen atas kualitas pelayanan yang diberikan perusahaan untuk memberikan kepuasan pada konsumen.

Kepuasan pelanggan adalah situasi yang ditunjukkan konsumen ketika kebutuhan atau keinginan mereka dapat terpenuhi dengan baik (Prasetyo, 2013). Hawknis dan Lonney dalam Suwito (2018) mengatakan kepuasan pelanggan memiliki beberapa indikator antara lain kesesuaian harapan, minat berkunjung kembali, dan kesediaan merekomendasikan. Kepercayaan konsumen merupakan hal yang sangat ingin didapatkan oleh semua perusahaan dari para konsumennya. Kepercayaan merupakan sebuah persepsi keyakinan dari sudut pandang konsumen atas keandalan penjual dalam pengalaman terpenuhinya harapan dan kepuasan konsumen. Menurut Mayer et al dalam Wong (2017) indikator kepercayaan adalah sebagai berikut : ability (keandalan), benevolence (kebaikan hati), integrity (integritas). 
Parasuraman et al dalam Lewis (2015) mendefinisikan kualitas pelayanan sebagai seberapa jauh perbedaan cara kerja yang diharapkan oleh pelanggan dengan kenyataan yang didapatkan. Dimensi untuk mengukur kualitas pelayanan yaitu tangibles (bentuk fisik), responsiveness (daya tanggap), reliability (reliabilitas), assurance (jaminan), empathy (perhatian). Kualitas layanan sangat berpengaruh dalam kemajuan suatu organisasi dan merupakan salah satu alat ukur keberhasilan dalam memberikan jaminan kepuasan bagi para pelanggan.

BUMDes Dana Asri Sejahtera yang terletak di Desa Wonoasri Kecamatan Tempurejo Kabupaten Jember merupakan salah satu bagian dari jasa simpan pinjam uang untuk menunjang upaya meningkatkan kesejahteraan masyarakat. Dalam memberikan pelayanan kepada nasabahnya pihak BUMDes menerapkan standart pelayanan yang sama, tidak pernah membedakan nasabah satu dengan nasabah yang lainnya. BUMDes Dana Asri Sejahtera menyediakan jasa tabungan, pinjaman, serta kredit barang dan sembako.

Fenomena yang terjadi yaitu sempat terjadinya penurunan jumlah nasabah peminjam dan penabung ditahun ke 3 yaitu tahun 2017 dimana terjadi penurunan jumlah orang yang menabung sebanyak 13 orang dan jumlah orang yang melakukan pinjaman hanya 10 orang. Penurunan tersebut disebabkan karena masih banyak masyarakat yang awam tentang informasi tabungan dan pinjaman serta kurangnya sosialisasi yang diberikan oleh pihak BUMDes kepada masyarakat, lalu tak jarang juga masyarakat merasa kurang puas atas pelayanan yang diberikan oleh pihak BUMDes. Pada masa itu pihak BUMDes juga sedang berada ditahap penyesuaian dalam menjalankan usaha yang baru didirikan tersebut, sehingga banyak masyarakat yang masih belum percaya dan meragukan kualitas pelayanan dari BUMDes Dana Asri Sejahtera.

Kualitas pelayanan yang kurang maksimal dan kurang memberikan rasa puas, sehingga belum menumbuhkan rasa percaya dari pihak nasabah untuk menggunakan jasa dari pihak BUMDES Dana Asri Sejahtera. Penelitian ini bertujuan untuk menguji dan menganalisis tangibles, responsiveness, reliability, assurance, dan empathy secara parsial dan simultan terhadap kepuasan nasabah pada BUMDes Dana Asri Sejahtera, serta untuk menguji dan menganalisis ability, benevolence, dan integrity secara parsial dan simultan terhadap kepuasan nasabah pada BUMDes Dana Asri Sejahtera. 


\section{TINJAUAN PUSTAKA}

\section{Pengertian Manajemen Pemasaran Jasa}

Manajemen pemasaran adalah segala rangkaian proses dalam perencanaan, menganalisis dan pengelolaan konsep untuk menetapkan harga, promosi dan distribusi yang dilakukan untuk mencapai tujuan perusahaan (Ettah \& Pondaag, 2019). Manajemen pemasaran jasa merupakan sebuah kegiatan yang output atau hasil akhirnya bukan berupa produk atau barang melainkan bersifat tidak terwujud dan ditunjang dengan peralatan yang canggih (Valerie A. et al, 2017 dalam Lewis, 2015). Kotler dan Amstrong (2012) menyatakan bahwa jasa memiliki 4 karakteristik yaitu : tidak terwujud (intangibility), tidak terpisahkan (inseparability), tidak tahan disimpan (perishability), bervariasi (variability).

\section{Pengertian Kualitas Pelayanan}

Kualitas pelayanan merupakan segala kegiatan pelayanan yang dilakukan perusahaan sebagai upaya untuk memenuhi kebutuhan dan memperoleh kepuasan pelanggan (Resti \& Soesanto, 2016). Moenir (2010) mengatakan bahwa pelayanan adalah kegiatan yang dilakukan oleh individu melalui sistem, prosedur dan metode untuk memenuhi kepentingan orang lain sesuai dengan kebutuhannya. Parasuraman, Zeithaml, dan Berry dalam Ramadhan (2013) menyatakan bahwa indikator kualitas pelayanan meliputi: tangibles (bentuk fisik), responsiveness (daya tanggap), reliability (reliabilitas), assurance (jaminan), empathy (perhatian).

\section{Pengertian Kepercayaan}

Sumarwan dalam Japlani et al. (2020) mengatakan bahwa kepercayaan konsumen merupakan semua pengetahuan yang didapatkan serta menjadi kesimpulan untuk subuah obyek, atribut dan manfaatnya. Menurut Harumi dalam Ettah dan Pondaag (2019), kepercayaan adalah sebuah keyakinan bahwa seseorang akan menemukan dan mendapatkan sesuatu yang mereka inginkan pada mitra pertukaran tersebut. Indikator kepercayaan menurut Mayer et al dalam Wong (2017) adalah sebagai berikut : ability (keandalan), benevolence (kebaikan hati), integrity (integritas). 


\section{Pengertian Kepuasan Pelanggan}

Kepuasan pelanggan menurut Brown dalam Sudaryana (2020) adalah suatu kondisi dimana kebutuhan, keinginan, dan harapan konsumen terhadap sebuah produk dan jasa, sesuai atau terpenuhi dengan penampilan produk dan jasa. Erviana (2013) berpendapat bahwa kepuasan pelanggan merupakan tanggapans secara emosional dari pengalaman terhadap produk atau jasa yang dibeli atau digunakan. Indikator kepuasan pelanggan meliputi kesesuaian harapan, minat berkujung kembali, kesedian merekomendasikan (Hawknis dan Lonney dalam Suwito, 2018).

\section{Kerangka Pikir}

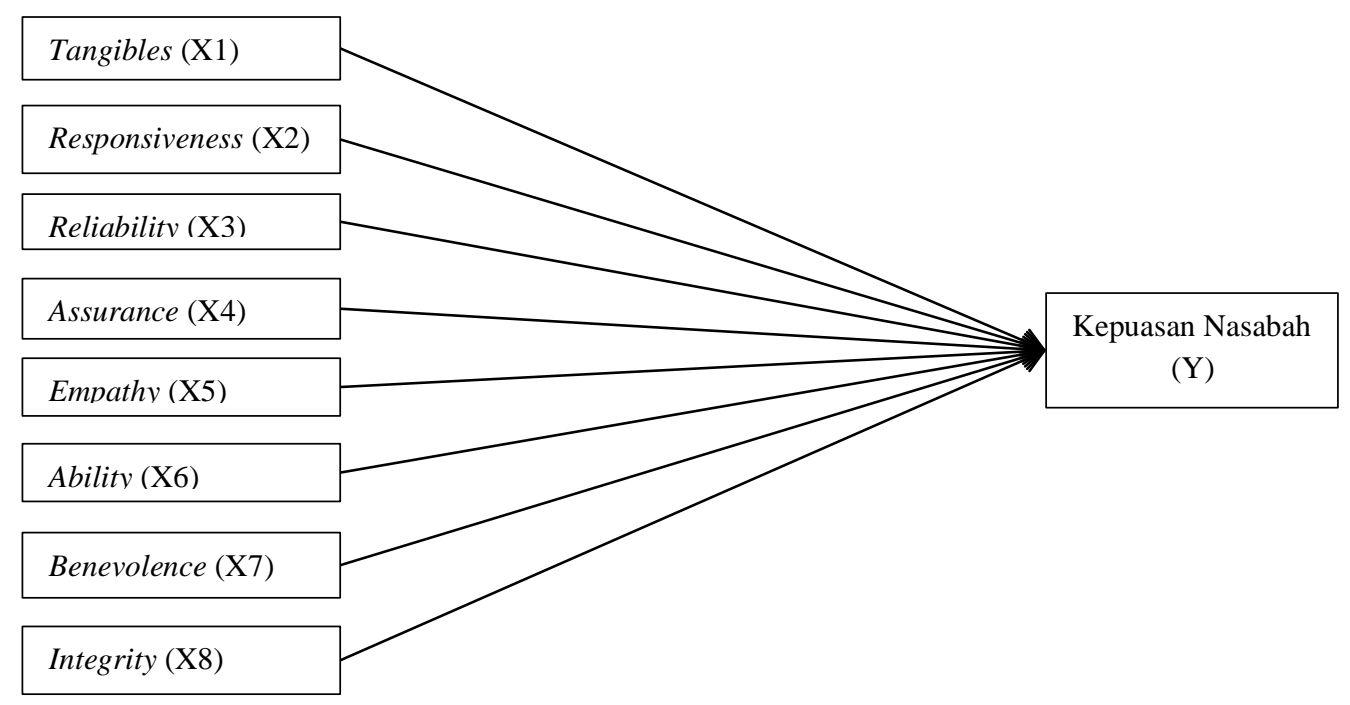

Gambar 1 Kerangka Pikir

\section{Hipotesis}

\section{Pengaruh tangibles terhadap kepuasan pelanggan}

Bukti fisik yang baik akan mempengaruhi persepsi konsumen. Aspek wujud fisik menjadi bagian penting sebagai alat ukur pelayanan jasa, karena jasa tidak bisa dilihat ataupun diraba. Parasuraman, Zeithaml, dan Berry dalam Adam (2015) mengatakan bahwa bukti fisik yang diberikan berupa penampilan karyawan, sarana yang dimiliki perusahaan. Semakin baik persepsi yang diberikan pelanggan terhadap bukti fisik maka kepuasan pelanggan semakin meningkat. Penelitian yang dilakukan oleh Soenaryo (2015) yang mengatakan bahwa tangibles berpengaruh positif dan signifikan terhadap kepuasan pelangan PT AJ Sequislife Cabang Trusty.

$\mathrm{H} 1$ : tangibles berpengaruh positif dan signifikan terhadap kepuasan pelanggan 


\section{Pengaruh responsiveness terhadap kepuasan pelanggan}

Respon atau kesigapan karyawan dalam membantu pelanggan dan memberikan pelayanan yang cepat serta tanggap sangat mempengaruhi tingkat kepuasan pelanggan. Parasuraman, Zeithaml dan Berry dalam Adam (2015) mengatakan pelayanan yang diberika secara cepat dan tanggap misalnya dalam menyampaikan informasi yang jelas kepada pelanggan dan tidak membiarkan pelanggan untuk menunggu terlalu lama agar tidak menimbulkan persepsi negatif terhadap kualitas pelayanann yang diberikan oleh perusahaan. Penelitian yang dilakukan oleh Suwito (2018) yang mengatakan bahwa responsiveness berpengaruh signifikan terhadap kepuasan konsumen dalam penggunaan jasa service dan perawatan CV Global AC Banjarbaru.

$\mathrm{H} 2$ : responsiveness berpengaruh positif dan signifikan terhadap kepuasan pelanggan.

\section{Pengaruh reliability terhadap kepuasan pelanggan}

Parasuraman, Zeithaml dan Berry dalam Adam (2015) mengatakan reliability atau keandalan merupakan kemampuan perusahaan untuk memberikan pelayanan sesuai dengan apa yang dijanjikan seperti ketepatan melayani pelanggan, menghindari melakukan kesalahan dalam pelayanan dan memberikan layanan yang akurat. Penelitian yang dilakukan oleh Yenni (2018) yang mengatakan reliability berpengaruh positif dan signifikan terhadap kepuasan pelanggan pada PT. PLN (PERSERO) unit Pelaksana Pelayanan Pelanggan (UP3) Makassaar Selatan.

H3 : reliability berpengaruh positif dan signifikan terhadap kepuasan pelanggan

\section{Pengaruh assurance terhadap kepuasan pelanggan}

Assurance atau jaminan merupakan kemamapuan karyawan atau perusahaan untuk menumbuhkan pengetahuan, kemampuan, sikap ramah tamah, sopan dan dapat dipercaya oleh pelanggan. Parasuraman, Zeithaml dan Berry dalam Adam (2015) mengatakan Perusahaan harus memiliki jaminan seperti keamanan sehingga pelanggan tidak merasa ragu dan dapat memberikan rasa percaya yang tinggi dalam menilai perusahaan. Hasil penelitian Sulaeman (2015) mengatakan bahwa assurance berpengaruh positif dan signfikan terhadap kepuasan pelanggan (studi kasus pada Charly VHT Family Karaoke cabang Garut).

$\mathrm{H} 4$ : assurance berpengaruh positif dan signifikan terhadap kepuasan pelanggan.

http://dx.doi.org/10.30587/mahasiswamanajemen.v2i01.2565 


\section{Pengaruh empathy terhadap kepuasan pelanggan}

Menurut Parasuraman, Zeethaml dan Berry dalam Adam (2015) empathy atau perhatian adalah kemampuan perusahaan dalam memberi perhatian yang tulus serta mendengarkan setiap keluhan dan keinginan mengenai pelayanan yang diberikan kepada pelanggan. Akbar (2016) mengatakan dalam penelitiannya bahwa empathy berpengaruh positif dan signifikan terhadap kepuasan pelanggan (studi pada Nasabah Prioritas PT. AIA Financial cabang Malang, Jawa Timur).

H5 : empathy berpengaruh positif dan signifikan terhadap kepuasan pelanggan.

\section{Pengaruh ability terhadap kepuasan pelanggan}

Ability atau kemampuan mengacu pada kompetensi karyawan atau perusahaan dalam memperngaruhi pelanggan. Dalam hal ini bagaimana karyawan atau perusahaan mampu menyediakan, memberikan layanan, dan memberi rasa aman dari gangguan pihak lain saat transaksi berlangsung (Mayer et al dalam David, 2017). Penelitian Muninggar (2017) mengatakan bahwa ability berpengaruh positif dan signifikan terhadap keputusan pembelian (studi kasus pada konsumen cuci mobil hidrolik Jitas Thoro Purbalingga).

H6 : ability berperngaruh positif dan signifikan terhadap kepuasan pelanggan.

\section{Pengaruh benevolence terhadap kepuasan pelanggan}

Mayer et al dalam David (2017) Benevolence atau kebaikan hati merupakan kemauan karyawan atau perusahanan dalam memberikan rasa puas yang saling menguntungkan antara perusahaan dan pelanggan. Indriani dan Nurcaya (2015) mengatakan dalam penelitiannya bahwa benevolence berpengaruh positif dan signifikan terhadap kepuasan pelanggan pada PT. Auto Bagus Rent a Car Denpasar. H7 : benevolence berpengaruh positif dan signifikan terhadap kepuasan pelanggan.

\section{Pengaruh integrity terhadap kepuasan pelanggan}

Integrity atau integritas berkaitan dengan perilaku atau kebiasaan penjual dalam menjalankan bisnisnya dan menunjukkan seberapa besar keyakinan pelanggan terhadap kejujuran karyawan atau perusahaan dalam menjaga dan memenuhi kesepakatan yang sudah dibuat dengan pelanggan (Mayer et al dalam David, 2017). Dalam penelitian yang dilakukan oleh Muninggar (2017) yang mengatakan integrity 
berpengaruh positif dan signifikan terhadap keputusan pembelian (studi kasus pada konsumen cuci mobil hidrolik Jitas Thoro Purbalingga).

H8 : integrity berpengaruh secara positif dan signifikan terhadap kepuasan pelanggan.

\section{METODOLOGI PENELITIAN}

\section{Objek Penelitian}

Objek penelitian yang dipilih dalam penelitian ini adalah BUMDes Dana Asri Sejehatera Desa Wonoasri, Kecamatan Tempurejo, Kabupaten Jember. Subjek penelitian ini adalah seluruh nasabah BUMDes Dana Asri Sejahtera.

\section{Jenis dan Sumber Data}

Desain penelitian yang digunakan dalam penelitian ini adalah penelitian asosiatif kausal menggunakan teknik kuantitatif. Data yang digunakan dalam penelitian ini adalah data primer dan data sekunder. Dimana data primer merupakan data yang didapat dari sumber aslinya dan data sekunder merupakan data yang didapat peneliti secara tidak langsung yaitu melalui penelitian terdahulu atau dokumentasi yang ada.

\section{Populasi dan Sampel}

Populasi merupakan jumlah keseluruhan dari objek penelitian. Populasi dalam penelitian ini adalah nasabah dari BUMDes Dana Asri Sejahtera Wonoasri yang berjumlah 552 orang. Sampel yang digunakan dalam penelitian ini adalah sebanyak 85 orang. Dengan teknik pengambilan sampel dalam penelitian ini menggunakan purposive sampling yaitu teknik pengambilan sampel pada sumber data tertentu (Sugiyono, 2014).

$$
\mathrm{n}=\frac{N}{1+N(e)^{2}}
$$

Keterangan: $\mathrm{N}=$ Jumlah populasi

$$
\begin{aligned}
& \mathrm{e}=\text { Tingkat kesalahan } \\
& \mathrm{n}=\text { Jumlah sampel }
\end{aligned}
$$

Populasi $(\mathrm{N})$ sebanyak 552 orang penumpang dengan asumsi tingkat kesalahan $(\mathrm{e})=$ $10 \%$, maka jumlah sampel (n) adalah :

$\mathrm{n}=\frac{552}{1+552(0.10)^{2}}$

$\mathrm{n}=84,6$ orang maka dibulatkan menjadi 85 orang. 


\section{Teknik Analisis Data}

Analisis regresi linier berganda dilakukan untuk mengetahui adanya keuatan hubungan antar dua variabel atau lebih, juga menunjukkan hubungan secara linier antara variabel dependen dan variabel independen. Analisis ini digunakan untuk memprediksi nilai dari variabel dependen apabila nilai variabel independen mengalami kenaikan atau penurunan.

$$
Y=a+b_{1} X_{1}+b_{2} X_{2}+e
$$

$\mathrm{Y}=$ Kepuasan Pelanggan

$\mathrm{a}=$ Bilangan Konstanta

$b_{1}=$ Koefisien regresi variabel kualitas pelayanan $\left(X_{1}\right)$

$b_{2}=$ Koefisien regresi variabel kepercayaan $\left(X_{2}\right)$

$\mathrm{X}_{1}=$ Kualitas pelayanan

$\mathrm{X}_{2}=$ Kepercayaan

$\mathrm{e}=$ Standart Error

\section{HASIL DAN PEMBAHASAN}

Hasil

\section{Karakteristik Responden Berdasarkan Jenis Kelamin}

Berdasarkan hasil penyebaran kuesioner terhadap 85 orang responden yang merupakan nasabah dari BUMDes Dana Asri Sejahtera, responden yang berjenis kelamin perempuan sebanyak 71,8 \% merupakan responden terbanyak. Secara pengelompokkan jenis kelamin disajikan pada Tabel 1.

Tabel 1. Tabel Jenis Kelamin Responden

\begin{tabular}{|l|c|c|}
\hline \multicolumn{1}{|c|}{ Jenis Kelamin } & Frekuensi & Persentase \\
\hline Laki - Laki & 24 Orang & $28.2 \%$ \\
\hline Perempuan & 61 Orang & $71,8 \%$ \\
\hline Total & 85 & $100 \%$ \\
\hline
\end{tabular}

(Sumber : Data yang diolah, 2021)

Berdasarkan Tabel ke-1 menunjukkan bahwa dari keseluruhan responden yang berjumlah 85 orang responden berjenis kelamin perempuan berjumlah 61 orang dengan jumlah persentae sebesar $71,8 \%$ dan responden laki-laki berjumlah 24 orang dengan persentase sebesar $28,2 \%$. 


\section{Karakteristik Responden Berdasarkan Pekerjaan}

Tabel 2. Karakteristik Responden Berdasarkan Pekerjaan

\begin{tabular}{|l|c|c|}
\hline \multicolumn{1}{|c|}{ Pekerjaan } & Frekuensi & Persentase \\
\hline Ibu Rumah Tangga & 26 Orang & $30,6 \%$ \\
\hline Pedagang & 36 Orang & $42,4 \%$ \\
\hline Petani & 11 Orang & $12,9 \%$ \\
\hline Lain-lain & 12 Orang & $14,1 \%$ \\
\hline Total & 85 & $100 \%$ \\
\hline
\end{tabular}

(Sumber : Data yang diolah, 2021)

Tabel ke-2 menunjukkan dari 85 orang responden, 26 orang responden bekerja sebagai Ibu Rumah Tangga, 36 orang bekerja sebagai pedagang, 11 orang bekerja sebagai petani, dan 12 orang berada di jenis pekerjaan lain-lain. Dari tabel diatas dapat diketahui persentasi tertinggi pekerjaan responden yakni 36 orang dengan persentase $42,4 \%$ dengan profesi sebagai pedagang.

\section{Karakteristik Responden Berdasarkan Lama Menjadi Nasabah}

Tabel 3. Karakteristik Responden Berdasarkan Lama Menjadi Nasabah

\begin{tabular}{|l|c|c|}
\hline \multicolumn{1}{|c|}{ Lama menjadi nasabah } & Frekuensi & Persentasi \\
\hline$<1$ Tahun & 26 Orang & $30,6 \%$ \\
\hline 1 - 3 Tahun & 42 Orang & $49,4 \%$ \\
\hline$>3$ Tahun & 17 Orang & $20 \%$ \\
\hline Total & 85 & $100 \%$ \\
\hline
\end{tabular}

(Sumber : Data yang diolah, 2021)

Berdasarkan tabel ke-3 mengenai karakteristik responden berdasarkan lama nasabah tersebut menjadi nasabah di BUMDes Dana Asri Sejahtera. Nasabah yang lama menjadi nasabah kurang dari satu tahun sebanyak 26 orang dengan persentase 30,6 \%, nasabah yang lama menjadi nasabah selama 1 sampai 3 tahun berjumlah sebanyak 42 orang dengan persentase sebanyak 49,4 \%, dan nasabah yang lama menjadi nasabahnya lebih dari 3 tahun atau bisa disebut nasabah lama berjumlah 17 orang dengan persentase $20 \%$.

\section{Uji Validitas}

Tabel 4. Hasil Uji Validitas

\begin{tabular}{|l|c|c|c|c|c|}
\hline \multicolumn{1}{|c|}{ Variabel } & Item & Koefisien Korelasi & r tabel & Sig. & Ket \\
\hline Tangibles & X1.1 & 0,814 & 0,213 & 0,000 & Valid \\
\hline & X1.2 & 0,575 & 0,213 & 0,000 & Valid \\
\hline & $\mathrm{X} 1.3$ & 0,823 & 0,213 & 0,000 & Valid \\
\hline Responsiveness & $\mathrm{X} 2.1$ & 0,819 & 0,213 & 0,000 & Valid \\
\hline & $\mathrm{X} 2.2$ & 0,878 & 0,213 & 0,000 & Valid \\
\hline & $\mathrm{X} 2.3$ & 0,779 & 0,213 & 0,000 & Valid \\
\hline
\end{tabular}




\begin{tabular}{|l|c|c|c|c|c|}
\hline \multicolumn{1}{|c|}{ Variabel } & Item & Koefisien Korelasi & r tabel & Sig. & Ket \\
\hline Reliability & X3.1 & 0,802 & 0,213 & 0,000 & Valid \\
\hline & X3.2 & 0,852 & 0,213 & 0,000 & Valid \\
\hline & X3.3 & 0,849 & 0,213 & 0,000 & Valid \\
\hline Assurance & X4.1 & 0,807 & 0,213 & 0,000 & Valid \\
\hline & X4.2 & 0,730 & 0,213 & 0,000 & Valid \\
\hline Empathy & X4.3 & 0,785 & 0,213 & 0,000 & Valid \\
\hline & X5.1 & 0,769 & 0,213 & 0,000 & Valid \\
\hline & X5.2 & 0,892 & 0,213 & 0,000 & Valid \\
\hline Ability & X5.3 & 0,763 & 0,213 & 0,000 & Valid \\
\hline & X6.1 & 0,824 & 0,213 & 0,000 & Valid \\
\hline & X6.2 & 0,756 & 0,213 & 0,000 & Valid \\
\hline Benevolence & X6.3 & 0,828 & 0,213 & 0,000 & Valid \\
\hline & X7.1 & 0,849 & 0,213 & 0,000 & Valid \\
\hline Integrity & X7.2 & 0,810 & 0,213 & 0,000 & Valid \\
\hline & X8.1 & 0,765 & 0,213 & 0,000 & Valid \\
\hline & X8.2 & 0,752 & 0,213 & 0,000 & Valid \\
\hline Kepuasan pelanggan & X8.3 & 0,762 & 0,213 & 0,000 & Valid \\
\hline & Y1.1 & 0,648 & 0,213 & 0,000 & Valid \\
\hline & Y1.2 & 0,684 & 0,213 & 0,000 & Valid \\
\hline & Y1.3 & 0,811 & 0,213 & 0,000 & Valid \\
\hline
\end{tabular}

(Sumber : Data yang diolah, 2021)

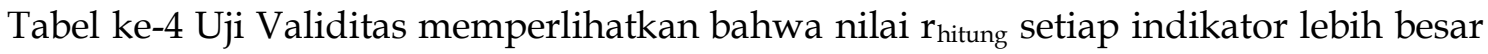
dari $\mathrm{r}_{\text {tabel. }}$ Dalam penelitian ini menggunakan 85 responden dengan nilai alpha 0,05 atau sebesar $5 \%$. $\mathrm{r}_{\text {tabel }}$ didapatkan dari rumus $\mathrm{df}=\mathrm{N}-2=85-2=83$ maka, diperoleh $\mathrm{r}_{\text {tabel }}$ sebesar 0,213. Jika hasil uji validitas $r_{\text {hitung }}$ menunjukkan lebih besar dari $r_{\text {tabel }}$ maka semua indikator pengukuran dalam kuesioner berstatus valid.

\section{Uji Reliabilitas}

Tabel 5. Hasil Uji Reliabilitas

\begin{tabular}{|l|c|c|}
\hline \multicolumn{1}{|c|}{ Variablel } & Cronbach alpha & Keterangan \\
\hline Tangibles & 0,795 & Reliabel \\
\hline Responsiveness & 0,834 & Reliabel \\
\hline Reliability & 0,841 & Reliabel \\
\hline Assurance & 0,814 & Reliabel \\
\hline Empathy & 0,830 & Reliabel \\
\hline Ability & 0,828 & Reliabel \\
\hline Benevolence & 0,852 & Reliabel \\
\hline Integrity & 0,807 & Reliabel \\
\hline Kepuasan pelanggan & 0,783 & Reliabel \\
\hline
\end{tabular}

(Sumber : Data yang diolah, 2021)

Tabel ke-5 hasil uji reliabilitas menunjukkan semua cronbach alpha atau semua nilai variabelnya lebih besar dari alpha 0,60 . Hal itu menunjukkan bahwa semua indikator yang terdapat pada masing masng variabel dapat dikatakan sudah reliable. Variabel 
dianggap reliable jika cronbach alpha $>0,60$, jika lebih kecil maka variabel yang diteliti tidak dapat dikatakan reliable.

\section{Analisis Regresi Linier Berganda}

\section{Tabel 6. Hasil Uji Regresi Linier Berganda}

\begin{tabular}{|c|c|c|c|c|c|c|c|c|}
\hline \multirow{2}{*}{\multicolumn{2}{|c|}{ Model }} & \multicolumn{2}{|c|}{$\begin{array}{l}\text { Unstandardized } \\
\text { Coefficients }\end{array}$} & \multirow{3}{*}{$\begin{array}{c}\text { Standardized } \\
\text { Coefficients } \\
\text { Beta }\end{array}$} & \multirow[b]{2}{*}{$\mathrm{T}$} & \multirow{3}{*}{$\begin{array}{l}\text { Sig. } \\
.000\end{array}$} & \multicolumn{2}{|c|}{$\begin{array}{l}\text { Collinearity } \\
\text { Statistics }\end{array}$} \\
\hline & & B & Std. Error & & & & Tolerance & VIF \\
\hline \multirow[t]{9}{*}{1} & (Constant) & 6.701 & \begin{tabular}{|l|}
1.499 \\
\end{tabular} & & 4.472 & & & \\
\hline & $\mathrm{X} 1$ & 1.264 & .113 & .205 & 11.155 & .000 & .498 & 2.006 \\
\hline & $\mathrm{X} 2$ & .995 & .102 & .174 & 9.730 & .000 & .528 & 1.895 \\
\hline & $\mathrm{X} 3$ & .960 & .096 & .185 & 9.967 & .000 & .489 & 2.044 \\
\hline & $\mathrm{X} 4$ & .793 & .125 & .108 & 6.348 & .000 & .582 & 1.719 \\
\hline & $\mathrm{X} 5$ & 1.237 & .100 & .208 & 12.355 & .000 & .593 & 1.686 \\
\hline & $\mathrm{X} 6$ & 1.132 & .079 & .242 & 14.381 & .000 & .591 & 1.691 \\
\hline & $\mathrm{X7}$ & 1.092 & .137 & .129 & 7.974 & .000 & .645 & 1.550 \\
\hline & $\mathrm{X} 8$ & 1.005 & .110 & .148 & 9.137 & .000 & .640 & 1.562 \\
\hline
\end{tabular}

a.Dependent Variable: $Y$

(Sumber : Data yang diolah, 2021)

Berdasarkan tabel ke-6 hasil uji regresi linier berganda diatas persamaan regresi yang dapat dituliskan dari hasil tersebut sebagai berikut :

$Y=6,701+1,264 X 1+0,995 X 2+0,960 X 3+0,793 X 4+1.237 X 5+1,132 X 6+1,092 X 7+$ $1,005 \times 8$

Penjelasan dari persamaan regresi diatas adalah :

1. Koefisien regresi kepuasan pelanggan $(\mathrm{Y})$ adalah positif 6,701 yang berarti apabila nilai dari variabel lainnya tetap atau konstan maka kepuasan pelanggan memiliki tingkat kepuasan nasabah sebesar 6,701.

2. Nilai koefisien tangibkes (X1) adalah sebesar 1,264 dan bernilai positif yang berarti variabel tangibles menunjukkan pengaruh positif terhadap peningkatan kepuasan nasabah pada BUMDes Dana Asri Sejahtera.

3. Koefisien regresi responsiveness (X2) menunjukkan nilai sebesar 0,995 dan bernilai positif yang berarti variabel menunjukkan pengaruh positif terhadap peningkatan kepuasan nasabah pada BUMDes Dana Asri Sejahtera.

4. Hasil penelitian koefisien regresi reliability (X3) adalah sebesar 0,960 dan bernilai positif yang berarti variabel reliability memiliki pengaruh positif dan apabila variabel reliability meningkat maka kepuasan nasabahya juga akan mengalami peningkatan. 
5. Nilai koefisien assurance (X4) adalah sebesar 0,793 dan bernilai positif yang berarti variabel assurance memiliki pengaruh positif dan apabila variabel assurance meningkat maka kepuasan nasabahya juga akan mengalami peningkatan.

6. Pada tabel 6 menunjukkan bahwa nilai koefisien empathy (X5) adalah sebesar 1,237 dan bernilai positif yang berarti variabel memiliki pengaruh positif dan apabila variabel empathy meningkat maka kepuasan nasabahya juga akan mengalami peningkatan.

7. Nilai X6 (ability ) koefisien regresinya dengan nilai sebesar 1,132 dan bernilai positif yang berarti variabel ability memiliki pengaruh positif dan apabila variabel ability meningkat maka kepuasan nasabahya juga akan mengalami peningkatan.

8. HasIl penelitian pada tebel 6 nilai koefisien benevolence (X7) adalah sebesar 1,092 dan bernilai positif yang berarti variabel benevolence memiliki pengaruh positif dan apabila variabel benevolence meningkat maka kepuasan nasabahya juga akan mengalami peningkatan.

9. Koefisien regresi integrity (X8) dengan nilai sebesar 1,005 dan bernilai positif yang berarti variabel integrity memiliki pengaruh positif dan apabila variabel integrity meningkat maka kepuasan nasabahya juga akan mengalami peningkatan.

\section{Uji Asumsi Klasik}

\section{Uji Multikolinieritas}

Tabel 7. Hasil Uji Multikolinieritas

\begin{tabular}{|c|c|c|c|c|c|c|c|c|}
\hline \multirow{2}{*}{\multicolumn{2}{|c|}{ Model }} & \multicolumn{2}{|c|}{$\begin{array}{c}\text { Unstandardized } \\
\text { Coefficients }\end{array}$} & \multirow{2}{*}{$\begin{array}{c}\text { Standardized } \\
\text { Coefficients } \\
\text { Beta } \\
\end{array}$} & \multirow[b]{2}{*}{$\mathrm{T}$} & \multirow[b]{2}{*}{ Sig. } & \multicolumn{2}{|c|}{$\begin{array}{c}\text { Collinearity } \\
\text { Statistics }\end{array}$} \\
\hline & & B & Std. Error & & & & Tolerance & VIF \\
\hline \multirow[t]{9}{*}{1} & (Constant) & 6.701 & 1.499 & & 4.472 & .000 & & \\
\hline & $\mathrm{X} 1$ & 1.264 & .113 & .205 & 11.155 & .000 & .498 & 2.006 \\
\hline & $\mathrm{X} 2$ & .995 & .102 & .174 & 9.730 & .000 & .528 & 1.895 \\
\hline & X3 & .960 & .096 & .185 & 9.967 & .000 & .489 & 2.044 \\
\hline & $\mathrm{X} 4$ & .793 & .125 & .108 & 6.348 & .000 & .582 & 1.719 \\
\hline & X5 & 1.237 & .100 & .208 & 12.355 & .000 & .593 & 1.686 \\
\hline & $\mathrm{X} 6$ & 1.132 & .079 & .242 & 14.381 & .000 & .591 & 1.691 \\
\hline & $\mathrm{X7}$ & 1.092 & .137 & .129 & 7.974 & .000 & .645 & 1.550 \\
\hline & $\mathrm{X} 8$ & 1.005 & .110 & .148 & 9.137 & .000 & .640 & 1.562 \\
\hline
\end{tabular}

a.Dependent Variable: $\mathrm{Y}$

(Sumber : Data yang diolah, 2021)

Berdasarkan tabel ke-7 diatas dapat dilihat bahwa nilai tolerance menunjukkan nilai tangibles sebesar 0,498, responsiveness sebesar 0,528, reliability sebesar 0,459, assurance sebesar 0,582 , empathy sebesar 0,593 , ability sebesar 0,591 , benevolence sebesar 0,645 , dan 
integrity sebesar 0,640. Dimana semua nilai menunjukkan angka lebih besar dari 0,1. Nilai VIF pada tangibles sebesar 2,006, responsiveness sebesar 1,895, reliability sebesar 2,044, assurance sebesar 1,719, empathy sebesar 1,686, ability sebesar 1,691, benevolence sebesar 1,550, dan integrity sebesar 1,562. Semua nilai VIF masing-masing variabel menunjukkan angka kurang atau tidak lebih besar dari angka 10. Maka dapat disimpulkan bahwa tidak terjadi multikolinieritas antar variabel bebas dalam model regresi yang digunakan dalam penelitian.

\section{Uji Heterokedastisitas}

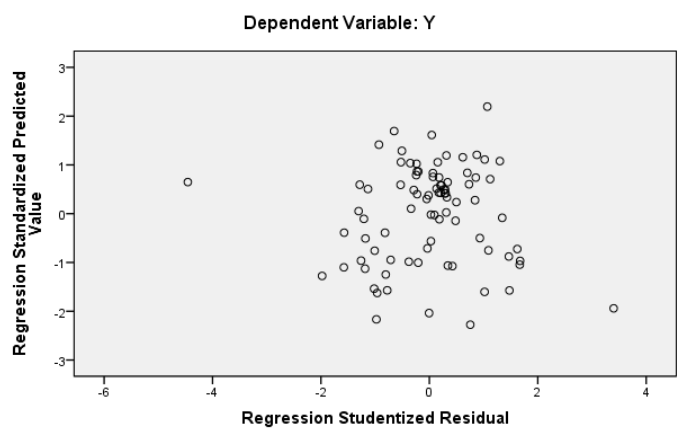

Gambar 2. Hasil Uji Heterokedastisitas

(Sumber : Data yang diolah, 2021)

Hasil analisis berdasarkan grafik scatterplot pada gambar 4.1 menunjukkan bahwa titiktitik menyebar secara acak dan tidak membentuk pola tertentu. Maka, grafik diatas mengindikasikan bahwa tidak ada gejala yang menunjukkan terjadinya heterokedastisitas

\section{Uji Normalitas}

Normal P-P Plot of Regression Standardized Residual

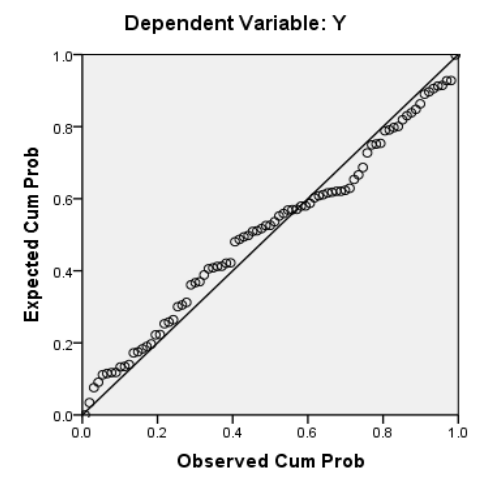

Gambar 3. Hasil Uji Normalitas

(Sumber : Data yang diolah, 2021) 
Pada gambar 4.2 grafik probability plot menunjukkan bahwa nilai residualnya tersebar merata dan mengikuti garis linier disepanjang garis diagonal. Maka, dapat disimpulkan bahwa model regresi pada grafik diatas memenuhi asumsi normalitas.

\section{Uji Hipotesis}

Uji t

Tabel 8. Hasil Uji t

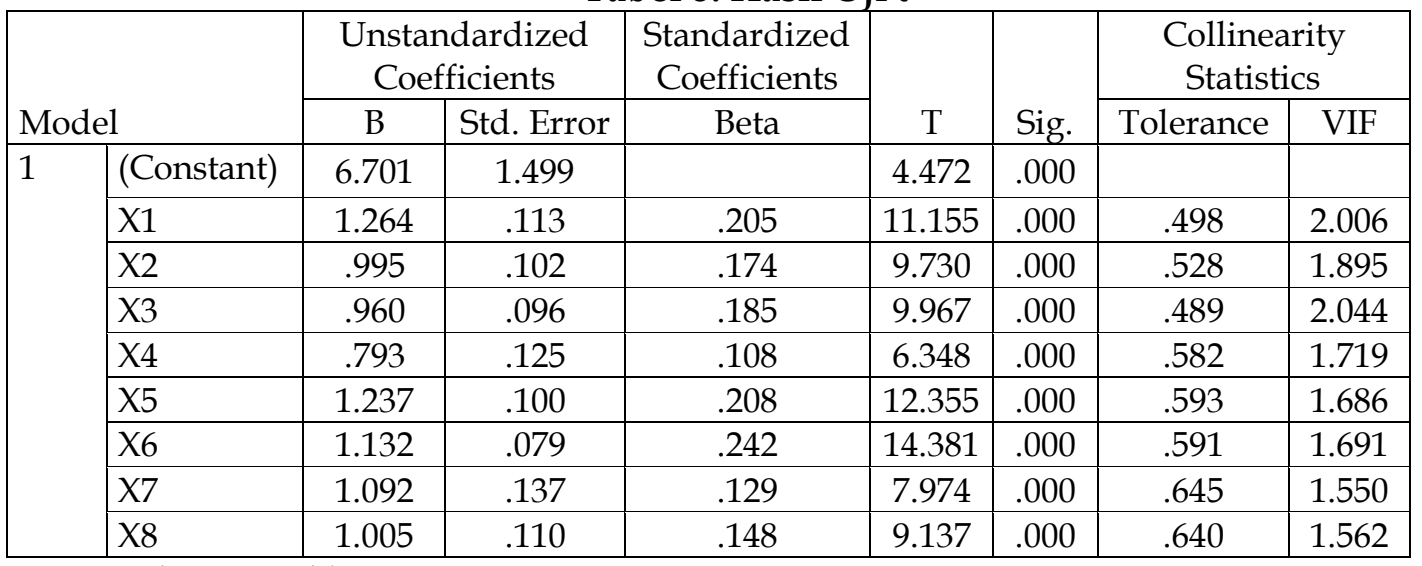

a.Dependent Variable: $Y$

(Sumber : Data yang diolah, 2021)

Berdasarkan tabel ke-8 dapat dijelaskan bahwa :

1. Pada variabel tangibles $(X 1)$ menunjukkan nilai $t_{\text {hitung }}>t_{\text {tabel }}(11,155>1,991)$ dan signifikan $<0,05(0.000<0,05)$, dengan demikian maka $\mathrm{H}_{0}$ ditolak dan $\mathrm{Hz}$ diteriman. Dapat diartikan bahwa hipotesis pertama, variabel tangibles dinyatakan berpengaruh signifikan secara parsial terhadap kepuasan nasabah BUMDes Dana Asri Sejahtera.

2. Variabel responsiveness $(X 2)$ menunjukkan nilai $t_{\text {hitung }}>t_{\text {tabel }}(9,730>1,991)$ dan signifikan $<0,05(0.000<0,05)$, dengan demikian maka $\mathrm{H}_{0}$ ditolak dan $\mathrm{Ha}$ diteriman. Dapat diartikan bahwa hipotesis kedua, variabel responsiveness dinyatakan berpengaruh signifikan secara parsial terhadap kepuasan nasabah BUMDes Dana Asri Sejahtera.

3. X3 (variabel reliability) menunjukkan nilai $t_{\text {hitung }}>t_{\text {tabel }}(9,967>1,991)$ dan signifikan $<0,05(0.000<0,05)$, dengan demikian maka $\mathrm{H}_{0}$ ditolak dan Ha diteriman. Dapat diartikan bahwa hipotesis ketiga, variabel reliability dinyatakan berpengaruh signifikan secara parsial terhadap kepuasan nasabah BUMDes Dana Asri Sejahtera.

4. Hasil Uji t pada tabel 4.18 menunjukkan variabel assurance (X4) memperoleh nilai $t_{\text {hitung }}>t_{\text {tabel }}(6,348>1,991)$ dan signifikan $<0,05(0.000<0,05)$, dengan demikian 
maka $\mathrm{H}_{0}$ ditolak dan $\mathrm{Ha}$ diteriman. Dapat diartikan bahwa hipotesis keempat, variabel assurance dinyatakan berpengaruh signifikan secara parsial terhadap kepuasan nasabah BUMDes Dana Asri Sejahtera.

5. Pada variabel empathy (X5) menunjukkan nilai $t_{\text {hitung }}>t_{\text {tabel }}(12,355>1,991)$ dan signifikan $<0,05(0.000<0,05)$, dengan demikian maka $\mathrm{H}_{0}$ ditolak dan $\mathrm{Ha}$ diteriman. Dapat diartikan bahwa hipotesis kelima, variabel empathy dinyatakan berpengaruh signifikan secara parsial terhadap kepuasan nasabah BUMDes Dana Asri Sejahtera.

6. Variabel ability $(X 6)$ menunjukkan nilai $t_{\text {hitung }}>t_{\text {tabel }}(14,381>1,991)$ dan signifikan $<0,05(0.000<0,05)$, dengan demikian maka $\mathrm{H}_{0}$ ditolak dan Hz diteriman. Dapat diartikan bahwa hipotesis keenam, variabel ability dinyatakan berpengaruh signifikan secara parsial terhadap kepuasan nasabah BUMDes Dana Asri Sejahtera.

7. Nilai variabel benevolence $(X 7)$ menunjukkan $t_{\text {hitung }}>t_{\text {tabel }}(7,974>1,991)$ dan signifikan $<0,05(0.000<0,05)$, dengan demikian maka $\mathrm{H}_{0}$ ditolak dan $\mathrm{Ha}$ diteriman. Dapat diartikan bahwa hipotesis ketujuh, variabel benevolence dinyatakan berpengaruh signifikan secara parsial terhadap kepuasan nasabah BUMDes Dana Asri Sejahtera.

8. Tabel 4.18 menunjukkan nilai variabel integrity (X8) sebesar $t_{\text {hitung }}>t_{\text {tabel }}(9,137>$ 1,991) dan signifikan $<0,05(0.000<0,05)$, dengan demikian maka $\mathrm{H}_{0}$ ditolak dan Hz diteriman. Dapat diartikan bahwa hipotesis kedelapan, variabel integrity dinyatakan berpengaruh signifikan secara parsial terhadap kepuasan nasabah BUMDes Dana Asri Sejahtera.

\section{Uji Kelayakan Model}

Uji F

Uji kelayakan model merupakan uji yang digunakan untuk mengukur ketepatan fungsi regresi secara statistik. Pengujian ini digunakan unruk mengetahui apakah semua variabel independen secara bersama-sama dapat berpengaruh terhadap variabel dependen, sehingga apabila terdapat pengaruh secara simultan antara variabel independen terhadap variabel dependen maka model regresi dapat dinyatakan layak sebagai model penelitian. 
Tabel 9. Hasil Uji F

\begin{tabular}{|l|l|r|r|r|r|r|}
\hline \multicolumn{2}{|l|}{ Model } & $\begin{array}{c}\text { Sum of } \\
\text { Squares }\end{array}$ & Df & $\begin{array}{c}\text { Mean } \\
\text { Square }\end{array}$ & F & Sig. \\
\hline \multirow{2}{*}{1} & Regression & 2756.480 & 1 & 2756.480 & 23.727 & $.000^{\mathrm{b}}$ \\
\cline { 2 - 7 } & Residual & 9642.414 & 83 & 116.174 & & \\
\cline { 2 - 7 } & Total & 12398.894 & 84 & & & \\
\hline
\end{tabular}

a. Dependent Variable: $\mathrm{Y}$

b. Predictors: (Constant), X8, X7, X2, X4, X5, X6, X1, X3

(Sumber : Data yang diolah, 2021)

Berdasarkan hasil output pada tabel ke-9, Uji kelayakan model menggunakan pengujian statisti F yang menunjukkan bahwa hasil $f_{\text {hitung }}>f_{\text {tabel }}$ atau dapat dibaca $f_{\text {hitung }}$ lebih besar nilainya dari pada $\mathrm{f}_{\text {tabel }}(23,727>2,06)$ dan hasil signifikasi sebesar $0.000<0,5$ atau dapat dibaca hasil signifikasi lebih kecil dari 0,05. Dengan demikian H0 ditolak dan Ha diterima. Maka dapat disimpulka bahwa secara bersama-sama variabel bebas tangibles, responsiveness, reliability, assurance, empathy, ability, benevolence, integrity berpengaruh signifikan secara simultan terhadap kepuasan nasabah BUMDes Dana Asri Sejahtera.

\section{Uji Koefesien Deretminasi}

Tabel 10. Hasil Uji Determinasi Koefiseien $\left(\mathbf{R}^{2}\right)$

\begin{tabular}{|c|c|c|c|c|c|c|c|c|c|}
\hline \multirow[b]{2}{*}{ Model } & \multirow[b]{2}{*}{$\mathrm{R}$} & \multirow[b]{2}{*}{$\begin{array}{c}\mathrm{R} \\
\text { Square }\end{array}$} & \multirow[b]{2}{*}{$\begin{array}{l}\text { Adjusted } \\
\text { R Square }\end{array}$} & \multirow{2}{*}{$\begin{array}{c}\text { Std. } \\
\text { Error of } \\
\text { the } \\
\text { Estimate }\end{array}$} & \multicolumn{5}{|c|}{ Change Statistics } \\
\hline & & & & & $\begin{array}{c}\mathrm{R} \\
\text { Square } \\
\text { Change }\end{array}$ & $\begin{array}{c}\text { F } \\
\text { Change }\end{array}$ & df1 & df2 & $\begin{array}{c}\text { Sig } \\
\text {. F } \\
\text { Change }\end{array}$ \\
\hline 1 & $.993^{a}$ & .986 & .984 & 1.53775 & .986 & 645.921 & 8 & 76 & .000 \\
\hline
\end{tabular}

a. Predictors: (Constant), X8, X7, X2, X4, X5, X6, X1, X3

b. Dependent Variable: $Y$

(Sumber : Data yang diolah, 2021)

Berdasarkan tabel ke-10 diatas dapat diketahui bahwa koefisien determinasi atau Adjusted R Square yang diperoleh sebesar 0,984. Hal ini berarti 98,4 \% kepuasan nasabah BUMDes Dana Asri Sejahtera dipengaruhi oleh variabel $X$ atau tangibles (X1), responsiveness (X2), reliability (X3), assurance (X4), empathy (X5), ability (X6), benevolene (X7) dan integrity (X8), sedangkan sisanya 1,6 \% kepuasan nasabah BUMDes Dana Asri Sejahtera dipengaruhi oleh variabel-variabel lainnya yang tidak diteliti dalam penelitian ini. 


\section{Pembahasan}

Berdasarkan hasil pengujian secara statistik dapat terlihat dengan jelas bahwa variabel bebas secara parsial dan simultan berpengaruh signifikan terhadap variabel terikat. Pengaruh yang diberikan kedelapan variabel bebas tersebut bersifat positif yang artinya semakin baik kualitas pelayanan dan kepercayaan yang diberikan maka semakin tinggi pula kepuasan yang diterima oleh nasabah. Penjelasan dari masing-masing pengaruh variabel dijelaskan sebagai berikut.

a. Pengaruh tangibles terhadap kepuasan nasabah BUMDes Dana Asri Sejahtera.

Berdasarkan pengujian statistik diatas indikator dari variabel kualitas pelayanan yakni tangibles menunjukkan pengaruh yang positif dan signifikan secara parsial dan simultan terhadap kepuasan nasabah BUMDes Dana Asri Sejahtera. Hal ini dapat mengindikasikan bahwa semakin baik dan rapi penampilan karyawan serta peralatan dan perlengkapan yang dimiliki semakin modern, maka akan semakin meningkatkan kepuasan dari nasabah BUMDes Dana Asri Sejahtera.

b. Pengaruh responsiveness terhadap kepuasan nasabah BUMDes Dana Asri Sejahtera Berdasarkan pengujian statistik diatas indikator dari variabel kualitas pelayanan yaitu responsiveness_menunjukkan pengaruh yang positif dan signifikan secara parsial dan simultan terhadap kepuasan nasabah BUMDes Dana Asri Sejahtera. Hal ini mengartikan bahwa semakin baik respon yang diberikan karyawan pihak BUMDes dalam merespon permintaan nasabah dan dalam membantu menyelesaikan kesulitan yang dialami nasabah, maka semakin meningkat kepuasan yang diterima oleh nasabah BUMDes Dana Asri Sejahtera.

c. Pengaruh reliability terhadap kepuasan nasabah BUMDes Dana Asri Sejahtera Berdasarkan pengujian statistik diatas indikator dari variabel kualitas pelayanan yakni reliability menunjukkan pengaruh yang positif dan signifikan secara parsial dan simultan terhadap kepuasan nasabah BUMDes Dana Asri Sejahtera. Hal ini menunjukkan bahwa semakin baik kemampuan yang dimiliki karyawan BUMDes dalam mengatasi keluhan, permasalahan nasabah dengan cepat dan tepat, juga kemampuan karyawan dalam menjawab pertanyaan yang diajukan oleh nasabah akan membuat rasa puas yang diterima nasabah semakin meningkat.

d. Pengaruh assurance terahadap kepuasan nasabah BUMDes Dana Asri Sejahtera Berdasarkan pengujian statistik diatas indikator dari variabel kualitas pelayanan yakni assurance menunjukkan pengaruh yang positif dan signfikan secara parsial 
dan simultan terhadap kepuasan nasabah BUMDes Dana Asri Sejahtera. Hal ini mengindikasikan bahwa semakin cara bersikap karyawan pihak BUMDes membuat nasabah merasa aman saat melakukan transaksi dan dapat menumbuhkan rasa percaya maka hal tersebut akan memberikan rasa puas dari nasabah atas pelayanan yang telah dilakukan oleh pihak BUMDes.

e. Pengaruh empathy terhadap kepuasan nasabah BUMDes Dana Asri Sejahtera Berdasarkan pengujian statistik diatas indikator dari variabel kualitas pelayanan yakni empathy menunjukkan pengaruh yang positif dan signifikan secara parsial dan simultan terhadap kepuasan nasabah BUMDes Dana Asri Sejahtera. Hal ini menunjukkan bahwa apabila pihak BUMDes semakin memahami dan mengutamakan kebutuhan nasabah, serta diberikannya perhatian secara khusus kepada nasabah akan memberikan rasa puas kepada nasabah.

f. Pengaruh ability terhadap kepuasan nasabah BUMDes Dana Asri Sejahtera Berdasarkan pengujian statistik diatas indikator dari variabel kepercayaan yakni ability menunjukkan pengaruh yang positif dan signifikan secara parsial dan simultan terhadap kepuasan nasabah BUMDe Dana Asri Sejahtera. Hal ini mengartikan bahwa semakin baik kemampuan karyawan dalam melayani nasabah dan disediakannya peralatan dan sarana yang dibutuhkan oleh nasabah akan menumbuhkan rasa percaya dan memberikan perasaan puas kepada nasabah.

g. Pengaruh benevolence terhadap kepuasan nasabah BUMDes Dana Asri Sejahtera Berdasarkan pengujian statistik diatas indikator dari variabel kepercayaan yaitu benevolence menunjukkan pengaruh yang positif dan signifikan secara parsial dan simultan terhadap kepuasan nasabah BUMDes Dana Asri Sejahtera. Hal ini mengindikasikan bahwa semakin pihak BUMDes memperlakukan nasabah dengan baik dan toleransi yang diberikan semakin tinggi maka akan memberikan rasa puas tersendiri kepada nasabah BUMDes Dana Asri Sejahtera.

h. Pengaruh integrity terhadap kepuasan nasabah BUMDes Dana Asri Sejahtera Berdasarkan pengujian statistik diatas indikator dari variabel kepercayaan yakni integrity menunjukkan pengaruh yang positif dan signifikan secara parsial dan simultan terhadap kepuasan nasabah BUMDes Dana Asri Sejahtera. Hal ini menunjukkan bahwa semakin baik kemampuan pihak BUMDes dalam memenuhi kebutuhan nasabah, cara bersikap karayawannya menunjukkan perilaku yang 
sopan dan jujur, serta memberikan jasa sesuai dengan apa yang telah dijanjikan akan memberikan rasa puas kepada nasabah.

\section{KESIMPULAN}

Berdasarkan hasil analisis dan pembahasan yang sudah diperoleh, maka dapat ditarik kesimpulan : Terdapat pengaruh positif dan signfikan antara variabel Kualitas Pelayanan yang memiliki dimensi tangibles, responsiveness, reliability, assurance, dan empathy serta variabel kepercayaan yang memiliki dimensi ability, benevolence dan integrity terhadap kepuasan nasabah pada BUMDes Dana Asri Sejahtera secara parsial dan simultan. Semakin baik pelayanan yang diberikan oleh BUMDes Dana Asri Sejahtera semakin menumbuhkan keyakinan dan kepercayaan terhadap nasabahnya untuk melakukan transaksi di BUMDes Dana Asri Sejahtera. Nasabah yang sudah merasakan pelayanan yang baik dan maksimal akan memberikan kepercayaan terhadap setiap jasa yang diberikan, Sehingga saat kepercayaan nasabah sudah muncul maka nasabah akan merasa puas.

\section{REKOMENDASI}

Berdasarkan hasil penelitian dan pembahasan yang menunjukkan bahwa masing-masing indikator dari variabel kualitas pelayanan dan kepercayaan menunjukkan pengaruh yang signfikan secara parsial dan simultan, maka saran yang diberikan yakni untuk perbaikan pelayanan BUMDes Dana Asri Sejahtera dimasa yang akan datang pihak bumdes sebaiknya semakin meningkatkan kinerja dari seluruh dimensi masing-masing variabel kualitas pelayanan seperti aspek menjaga penampilan karyawan, meningkatkan kemampuan karyawan dalam memberikan informasi kepada nasabahnya, meningkatkan kemampuan menyelesaikan keluhan nasabah dengan cepat dan tepat, selalu memberi kemudahan dan rasa aman kepada nasabah, selalu mengutamakan kepentingan nasabah. Dengan perbaikan kualitas pelayanan tersebut akan membentuk kepercayaan nasabah terhadap BUMDes Dana Asri Sejahtera.

Keterbatasan penelitian yang dialami dari penelitian ini adalah jumlah responden yang hanya 85 orang tentunya masih kurang untuk menggambarkan keadaan yang sesungguhnya dan informasi yang diberikan responden melalui kuesioner terkadang tidak menunjukkan kejadian yang sebenarnya, karena terkadang disebabkan oleh terjadinya perbedaan pemikiran, anggapan dan pemahaman pada 
setiap responden. Maka disarankan kepada peneliti selanjutnya untuk mengambil sampel yang lebih banyak agar mendapatkan data dan hasil yang lebih akurat.

\section{DAFTAR PUSTAKA}

Erviana, O. (2013). Pengaruh Kualitas Pelayanan dan Kepercayaan terhadap Kepuasan Pasien Rawat Inap di RSUD Dr. Soewondo Kendal. In Fakultas Ekonomi.

Ettah, Nadhya Pingkan. Pondaag, J. J. (2019). Pengaruh Kepercayaan, Kepuasan Konsumen Dan Kualitas Pelayanan Terhadap Loyalitas Konsumen Dalam Pembelian Mobil Pada Pt. Hasjrat Abadi Manado. Jurnal EMBA: Jurnal Riset Ekonomi, Manajemen, Bisnis Dan Akuntansi, 7(3). https://doi.org/10.35794/emba.v7i3.24056

Japlani, A., Fitriani, F., \& Mudawamah, S. (2020). Pengaruh Kualitas Pelayanan, Kepercayaan Terhadap Kepuasan Nasabah Pada Cabang Bmt Fajar Metro Pusat. Fidusia: Jurnal Keuangan Dan Perbankan, 3(1), 67-85. https://doi.org/10.24127/jf.v3i1.469

Lewis, B. R. (2015). Servqual. In Wiley Encyclopedia of Management (pp. 1-1). https://doi.org/10.1002/9781118785317.weom090654

Prasetyo, W. B. (2013). Pengaruh kualitas pelayanan, kepercayaan dan kepuasan terhadap loyalitas pelanggan (studi pada swalayan luwes purwodadi ). Jurnal Manajemen Pemasaran, 1-13.

Resti, Devi; Soesanto, H. (2016). Pengaruh Persepsi Harga, Kualitas Pelayanan melalui Kepuasan Pelanggan terhadap Minat Beli Ulang pada Rumah Kecantikan Sifra Di Pati. Diponegoro Journal of Management, 5(1), 1-12.

Sudaryana, Y. (2020). Pengaruh Kualitas Pelayanan, Kepercayaan Dan Harga Terhadap Kepuasan Konsumen Pada Kantor Pos Indonesia (Persero) Kota Tangerang. Journal of Management Review, 4(1), 447-455.

Suwito, J. (2018). No Titl えe. 112, 255-262.

Wong, D. (2017). Pengaruh Ability, Benevolence Dan Integrity Terhadap Trust, Serta Implikasinya Terhadap Partisipasi Pelanggan E-Commerce: Studi Kasus Pada Pelanggan E-Commerce Di Ubm. Jurnal Riset Manajemen Dan Bisnis (JRMB) Fakultas Ekonomi UNIAT, 2(2), 155-168. https://doi.org/10.36226/jrmb.v2i2.46 